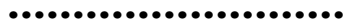

Basic and Clinical Science of Mental and Addictive Disorders 


\section{Bibliotheca Psychiatrica}

No. 167

Series E ditor

B. Saletu, Vienna

KARGER $\begin{aligned} & \text { Basel - Freiburg - Puris - London - New York' } \\ & \text { New Delhi - Bangkok - Singapore - Tokyo - Sydney }\end{aligned}$ 


\title{
Basic and Clinical Science of Mental and Addictive Disorders
}

Volume Editors

\author{
L.L. J udd, La Jolla, Calif. \\ B. Saletu, Vienna \\ V. Filip, Prague
}

22 figures, 10 in color and 33 tables, 1997

KARGER $\begin{aligned} & \text { Basel - Freiburg - Puris - London - New York } \\ & \text { New Delhi - Bangkok - Singapore - Tokyo - Sydncy }\end{aligned}$ 


\title{
Bibliotheca Psychiatrica
}

\author{
Library of Congress Cataloging-in-Publication D ata \\ Basic and clinical science of mental and addictive disorders / volume editors, L.L. J udd, B. Saletu, V. Filip. \\ (Bibliotheca psychiatrica; no. 167) \\ Proceedings from the Collegium Internationale $\mathrm{N}$ euro-Psychopharmacologicum (CIN P) R egional Confer- \\ ence held on June 10-12, 1995 in Vienna and Prague. \\ Includes bibliographical references and indexes. \\ 1. Psychiatry - Congresses. I. J udd, L ewisL. II. Saletu, Bernd. III. Filip, V. (Vaclav) IV. Collegium Interna- \\ tionale N euro-psychopharmacologicum. Regional Conference (1995: Vienna, Austria, and Prague, Czech \\ Republic) V. Series. \\ [DNLM : 1. M ental Disorders - diagnosis - congresses. 2. M ental Disorders - therapy - congresses. \\ 3. B ehavior, A ddictive - diagnosis - congresses. 4. B ehavior, A ddictive - therapy - congresses. \\ W 1 BI 429 no. 1671997 / W M 140 B311 1997] RC327.B37 1997616.86 - dc21 \\ ISBN 3-8055-6385-X (hardcover)
}

D rug D osage. The authors and the publisher have exerted every effort to ensure that drug selection and dosage set forth in this text are in accord with current recommendations and practice at the time of publication. H owever, in view of ongoing research, changes in government regulations, and the constant flow of information relating to drug therapy and drug reactions, the reader is urged to check the package insert for each drug for any change in indications and dosage and for added warnings and precautions. This is particularly important when the recommended agent is a new and/or infrequently employed drug.

All rights reserved. No part of this publication may be translated into other languages, reproduced or utilized in any form or by any means electronic or mechanical, including photocopying, recording, microcopying, or by any information storage and retrieval system, without permission in writing from the publisher.

(c) Copyright 1997 by S. K arger AG, P.O. Box, CH-4009 Basel (Switzerland) Printed in Switzerland on acid-free paper by Thür AG O ffsetdruck, Pratteln ISBN 3-8055-6385-X 


\section{Contents}

XI Preface

Clinical and Public Health Significance of Chronic Subsyndromal States:

Mental Disorders or Normal Variations?

1 Diagnosis and Classification of Neurasthenia

Sartorius, N. (G eneva)

6 The Role of Subsyndromal Depressive Symptoms in Unipolar Major Depression

Judd, L.L .; Paulus, M .; A kiskal, H.S.; R apaport, M .H .;

Kunovac, J.L. (La Jolla/San D iego, Calif.)

11 Diagnosis and Treatment of Subsyndromal Seasonal Affective Disorder K asper, S.; Praschak-R ieder, N. (Vienna)

21 Chronic Fatigue Syndrome Wessely, S. (L ondon)

29 Chronic Disturbances of Temperament A kiskal, H.S. (L a Jolla, Calif.)

33 Recurrent Brief Psychiatric Syndromes: Hypomania, Depression, Anxiety and Neurasthenia A ngst, J. (Zürich)

39 Milder Depressive Chronicity: An Important Clinical Problem Paykel, E.S. (C ambridge)

44 Mild Neurocognitive Disorder Grant, I. (San D iego, Calif.)

Applications of Functional Brain Imaging to Solve Clinical Problems

54 Visualizing the Living Human Brain. The Techniques and Promise of EEG and Event-Related Potentials Mapping

Saletu, B. (Vienna) 
63 Visualizingthe LivingH uman Brain. The Techniqueand Promise of Magnetic Resonance Imaging and Magnetic Resonance Spectroscopy

M ann, K .; Bartels, M . (Tübingen)

Applications of Molecular Biology and Genetics to Solve Clinical Problems

68 The 'Novel' Dopamine Receptors: Psychiatric Implications Schwartz, J.-Ch.; Sokoloff, P. (Paris)

75 Multiple Receptor Subtypes: The Impact of Molecular Biology on Pharmacology and Drug Discovery

L anger, S.Z. (Bagneux)

82 Contributions of Molecular Geneticsto the Understanding of Bipolar Depression

M endlewicz, J.; Souery, D. (Brussels)

89 The Genetics of Schizophrenia

Cardno, A .G.; M urphy, K .C.; M cG uffin, P. (C ardiff)

New Frontiers in Clinical Science: Schizophrenia

105 Developmental Malformations in Cerebral Structures of Schizophrenic Patients

Beckmann, H. (Würzburg)

111 Cerebral Asymmetry, Language and Psychosis

Crow, T.J. (Oxford)

New Frontiers in Clinical Science: Alzheimer's Disease

115 Genetics of the Alzheimer Diseases

Roses, A.D. (D urham, N.C.)

119 Apolipoprotein E and Neurofibrillary Tangles in Alzheimer's Disease

O hm, T.G . (Berlin); Scharnagl, H .; M ärz, W. (F reiburg)

123 The Amplifying Effect of $\beta$-Amyloid on Cellular Calcium Signalling in Alzheimer's Disease

M üller, W.E.; Eckert, A .; H artmann, H .; Förstl, H . (M annheim)

128 Prospective Genetic Epidemiology of Dementia in the Very Old A Itstiel, L.D. (N ew York, N.Y./Indianapolis, I nd.); G reenberg, D.; Lantz, M .; L ebow, L .; M arin, D.; Zhou, G.L .; K eddache, M .; Yang, X .-P.; M ohs, R.

(N ew York, N.Y.) 
New Frontiers in Clinical Science: Alcoholism and Drug Addiction

136 Craving in Alcohol Dependence: Pharmaceutical Interventions

L esch, O.M .; Benda, N.; G utierrez, K .; Walter, H.; (K alksburg)

148 Sardinian Alcohol-Preferring Rats: An Animal Model of Alcoholism

Colombo, G .; A gabio, R .; Balakievskaia, N .; L obina, C.; R eali, R .; Fadda, F.;

G essa, G.L. (Cagliari)

150 Preclinical Effects of Drugs of Abuse

Šulcová, A. (Brno)

153 Opioid Receptor Heterogeneity: The Use of New Ligands

M árki, Á. (Szeged); H osztafi, S. (Tiszavasvári); Ötvös, F. (Szeged);

Schmidhammer, H . (Innsbruck); Tóth, G.; Borsodi, A . (Szeged)

155 Biological Factors Modulating Drug Reward

Zvartau, E.; K uzmin, A .; Patkina, N .; Semenova, S.; Bespalov, A .;

Vekovischeva, O. (St. Petersburg)

New Frontiers in Clinical Science: Suicide and Mood Disorders

162 C urrent Concepts of Mechanisms of Action of Antidepressant Treatments Based on Preclinical Studies

Vetulani, J. (Cracow)

168 Clinical and Neurobiological Risk Factors for Suicidal Behavior

M ann, J.J.; M alone, K .M .; U nderwood, M .D.; A rango, V. (N ew York, N.Y.)

171 Studies of Suicide and Suicidal Behavior in Hungary

R inmer, Z. (Budapest)

New Aspects of the Calcium Channel Blocker and Antiglutamatergic Drug, Caroverine

175 Which Phencyclidine-Like N-Methyl-D -Aspartate Receptor Antagonists Are Currently Available for Clinical Use?

K ornhuber, J. (G öttingen); Weller, M . (Tübingen); R iederer, P. (Würzburg)

181 Caroverine Depresses the Activity of Cochlear Glutamate Receptors (in vivo Model for Drug-Induced Neuroprotection)

Ehrenberger, K . (Vienna); F elix, D. (Berne)

184 Central Effects of Acute, Intravenous and Oral Caroverine in Man: Double-Blind, Placebo-Controlled EEG Mapping and Psychometry Sal etu, B.; G rünberger, J.; A nderer, P.; L inzmayer, L . (Vienna)

190 On the Cerebro-Protective Effects of Caroverine: Double-Blind, PlaceboControlled, EEG Mapping and Psychometric Studies under Hypoxia

A nderer, P.; Saletu, B. (Vienna) 
195 Caroverine, a Well-Known Drug with Glutamatergic Effects and New Therapeutic Possibilities

K önig, P.; Bieberschulte, W. (R ankweil)

198 Caroverine in the Therapy of Cochlear-Synaptic Tinnitus:

A Placebo-Controlled Blind Study

D enk, D.-M .; E hrenberger, K . (Vienna)

New Developments in Social Phobia

201 Epidemiology of Social Phobia

L épine, J.-P.; Pélissolo, A . (Paris)

205 Psychological Treatment of Social Phobia

Clark, D.M . (Oxford)

209 Quality of Life in Social Phobia

K atschnig, H. (Vienna)

New Aspects of Atypical Neuroleptics

212 Adverse Effects of Atypical Antipsychotics

F leischhacker, W.W.; H ummer, M . (Innsbruck)

219 Effects of Atypical Antipsychotics on Polysomnograpic Measures in Schizophrenia

Tandon, R. (A nn A rbor, M ich.)

223 Neurophysiological Aspects of Positive and Negative Schizophrenia and Therapeutic Consequences: Trials with Benzamides

Saletu, B.; A nderer, P.; G rünberger, J.; K üfferle, B. (V ienna)

Selegiline in Alzheimer's Disease

232 Treatment Strategies in Alzheimer's Disease

Tariska, P. (Budapest)

235 Possible Benefits of a Combination of Selegiline and Cholinesterase Inhibitors

Schneider, L.S.; Olin, J.T.; Pawluczyk, S. (L os A ngeles, Calif.)

238 Selegiline Slows Down the Decline of Cognitive and Electrophysiological Functions in Alzheimer's Disease

Filip, V.; D avid, I.; K laschka, J.; K olibáš, E . (Prague)

Tiapridal

241 The Pharmacological Properties of Tiapride

Sanger, D.J.; Perrault, G.; Schoemaker, H.; Scatton, B. (Bagneux) 
244 Sensory Aspects in Tic Disorders

Rothenberger, A . (G otttingen)

Teaching of Psychopharmacology

247 Teaching Psychopharmacology in Central and Eastern Europe H albreich, U. (Buffalo, N.Y.)

250 Author Index

252 Subject Index 


\section{Preface}

This monograph contains the proceedings from the plenary sessions and the oral presentations of the satellite meetings of the Collegium I nternationale $\mathrm{N}$ euro-Psychopharmacologicum (CIN P) Regional Conference held on July 10-14, 1995, in Vienna and Prague. The theme of this CIN P R egional Conference was ' $\mathrm{N}$ euroscience and $\mathrm{N}$ europsychopharmacology in the $\mathrm{E}$ ast and West at the Beginning of the European D ecade of Brain Research'. The concept for such a meeting evolved from a program, which I articulated, as President of CINP, to reach out to our scientific colleagues in Eastern and Central Europe with the CINP to promote collaborations and scientific exchange During the XIX th CINP Congress in Washington, D.C., in June of 1994, several meetings were held with many of the representatives from the scientific communities in Central and Eastern Europe who were attending the CIN P Congress. What emerged from these discussions was a consensus behind the idea of organizing a CIN P-sponsored meeting which would involve basic and clinical scientists from E astern and Central Europe with scientists from other nations, especially Western Europe, as a first step in an effort to improve communication, enhance friendships and collaborations with scientists from all parts of the world with the relevant scientific communities in Eastern and Central Europe.

A nother important goal of the 1995 CINP Regional Conference was to acquaint neuroscientists and neuropsychopharmacologists from $E$ astern and Central Europe with the CINP and to encourage interested and qualified scientists to join and participate in CIN P activities. The response both to the proposed CIN P R egional Conference and to the CIN P itself by our colleagues in Eastern and Central Europe was very gratifying and encouraging. To sym- 
bolize the joining of the 'E ast and West' a decision was made to convene the conferencein two different cities, and as a result, Vienna, one of the easternmost cities of Western E urope, and Prague, one of the westernmost cities of Eastern E urope, were selected. The first 2 days of the R egional Conference were held in Vienna and the final 2 days in Prague with a travel day in between. Over 500 scientific delegates attended the Regional Conference, making it one of the most successful regional meetings held by the CIN P.

The overriding principles in developing the scientific program for the 1995 CIN P R egional Conference was first, to include only presentations that represented the very best of basic and clinical neuropsychopharmacology and neuroscience at the very cutting edge of our field. Second, every attempt was made to be as representative as possible, in an international sense, and to invite presentations from scientists from as many of the European countries as possible, both E ast and West. Third, given the increasingly important role of basic neurosciencein fueling discovery in the mental, substanceuse disorders and disorders of aging was to emphasizeand integrate presentations on relevent basic neuroscience and neuropsychopharmacology topics. In crafting the program, the Scientific Program Committee applied all these principles very effectively in selecting the speakers and in organizing the program. We owe them our gratitude for a job well done The Scientific Program Committee consisted of Vaclav Filip (Czechia), Salomon Langer (France), Julien M endlewicz (Belgium), G iorgio Racagni (I taly), O akley R ay (USA ), B ernd Saletu (A ustria), J ean Charles Schwarz (France) and myself (USA).

The first day of this unusual CIN P R egional Conference was convened in Vienna and was devoted to a very important, but largely ignored, clinical and public health problem presented by subsyndromal forms of mood, anxiety and cognitive disorders. This is the first scientific meeting, at the international level, to focus on this very important topic and the presentations represented the best data and thinking available on these important subsyndromal states. Since the CIN P R egional Conference was held in 1995, most likely stimulated by the presentations from the Conference, an increasingly powerful compilation of scientific evidence is emerging on the clinical and public health importance of the subsyndromal states in the community, in primary care and mental health settings. These presentations on subsyndromal disorders are included in Chapter 1. The second day in Vienna concentrated on the applications of new technologies of functional brain imaging (Chapter 2) and of cell and molecular biology (Chapter 3) to solve the clinical problems presented by severe mental disorders. Presentations also covered the use of molecular genetic methodologies in the study of bipolar and other disorders. A spects of these chapters also described the promise of new psychotropic drug discovery through the use of modern molecular biology techniques. 
The topics for days three and four (Chapters 4-7) cover the presentations that were made during the 2 days in Prague. The general topic area for each chapter was chosen by representatives from the scientific community in Eastern and Central Europe. The primary focus in each of these topic areas of schizophrenia, A Izheimer's disease, alcoholism and drug addiction and suicide and the mood disorders was to present recent updates of the clinical science in each topic area. Chapters 8-11 involve presentations from satellite symposia that were held in conjunction with the 1995 CIN P R egional Conference. These presentations covered the new clinical characteristics of a calcium channel blocker, new developments in the treatment of social phobia, and new aspects of the atypical neuroleptics. Chapters 11 and 12 involve specific recent clinical studies of two new agents in the treatment of A lzheimer's disease and G illes de la Tourette syndrome. The final chapter (Chapter 13) describes the new curriculum on normal and abnormal human behavior, which has been developed by the CINP Educational Committee for use in CINP-sponsored educational training programs directed toward developing countries. In summary, each of the scientific presentations during the 4 days of the CINP Regional Conference represented the very best of what our field has to offer on each topic.

The compendium of data included in this monograph range broadly and cover many of the most relevant topics of high clinical and public health importance for our field. This compilation in its entirety is a symbolic benchmark of the enormous progress that is being made in neuroscience and neuropsychopharmacology to better understand, diagnose and treat mental and addictive disorders and disorders of the aging. We believe there will be something of interest in this volume for the basic and clinical scientist, and for clinical practitioners who diagnose and treat patients with brain disorders.

Lewis L. J udd, M D

President, Collegium Internationale

N euro-Psychopharmacologicum 